\title{
Comparative study between biological and chemical control programs of certain sweet pepper pests in greenhouses
}

\author{
S. A. El Arnaouty' , A. H. El-Heneidy², Amal I. Afifi ${ }^{1}$, I. H. Heikal ${ }^{3}$ and Mona N. Kortam³
}

\begin{abstract}
Sweet pepper is an important vegetable crop in Egypt. It is cultivated for local consumption and exportation. The crop is attacked by a large number of pest species such as Western flower thrips, Frankliniella occidentalis (Pergande), whitefly, Bemisia tabaci (Genn.), the two-spotted spider mite, Tetranychu surticae Koch, and the beet armyworm, Spodoptera exigua (Hubner). The present study was conducted on the sweet pepper cultivated in greenhouses, during the winter plantation 2016/17 in a commercial farm located at Berkash district, Giza Governorate, Egypt. Three control programs were practiced: the first used biological control agents (BC), the predators, Orius albidipennis (Reuter), Macrolophus caliginosus (Wagner), Chrysoperla carnea (Steph.), and the egg parasitoid, Trichogramma euproctidis (Girault); the second was sprayed by the recommended chemical control program of the farm (CC); and the third was untreated as a control. Obtained results revealed that the BC program was the most significant one for controlling the complex of sweet pepper pests. Also, applying the BC program resulted to a high yield of sweet pepper production (35.06\% increasing than the control).
\end{abstract}

Keywords: Sweet pepper, Biocontrol agents, Chemical control, Yield, Greenhouses

\section{Background}

Sweet pepper is one of the important vegetable crops in Egypt that cultivated for local consumption and exportation (El-Laithy et al. 2013). The land area devoted to greenhouses production of color sweet peppers has been increased substantially over the past decade. In Egypt, it reached 400 ha with total plant-houses area of 11,300 ha (El Arnaouty et al. 2018). Also, pepper production is affected by different environmental and management systems, where it ranged from 5 to $28.8 \mathrm{~kg} / \mathrm{m}^{2}$ and export percentage ranged from 50 to $90 \%$.

Sweet pepper is attacked by a large number of pests from seedling stage to mature plants. Kortam (2019) recorded 4 major pest species that limit the production and have forced farmers to use chemical insecticides

\footnotetext{
* Correspondence: sweetdays13@yahoo.com

${ }^{3}$ Central Laboratory of Organic Agriculture, Agricultural Research Center, Giza, Egypt

Full list of author information is available at the end of the article
}

deliberately, those are the following: the Western flower thrips, Frankliniella occidentalis (Pergande); the whitefly, Bemisia tabaci (Genn.); the two-spotted spider mite, Tetranychus urticae Koch; and the beet armyworm, Spodoptera exigua (Hubner).

F. occidentalis is a worldwide key pest of most of the greenhouses' flower and vegetable crops, distorting flowers, and leaves by feeding and transmitting viruses (Driesche et al. 2006). Chemical control is the dominant method of the thrips management used by greenhouse growers, but has proved rather unsuccessful. Hence, developing biological control strategies against thrips infestations can be an alternative tool.

The whitefly, B. tabaci, is also a serious pest in greenhouses and is often seen on fuchsias, poinsettias, cucumbers, lettuce, and tomatoes causing great damages by feeding and transmitting viruses (Adly 2016).

The two-spotted spider mite, T.urticae, is a ubiquitous and economically important agricultural pest feeding on 
a wide range of host plant species (Heikal and Ebrahim 2013). The economic threshold of the spider mite population density should not exceed 3 motile forms per leaf (Warabieda 2015). Under favorable conditions, spider mites can rapidly build up to very high populations as they are characterized by a high reproductive capacity, causing important economic damages as yield losses can reach 90\% (Ginette et al. 2014).

The beet armyworm, S. exigua, is a polyphagous pest species on many important cultivated crops. It has a worldwide distribution in tropical and subtropical regions (Wakamura 1990). It is known as a greenhouse pest (Lasa et al. 2007). Host plants include various economically important crops such as tomato, Brassica, Capsicum, onion, and maize (Capinera 2014).

Controlling greenhouse pests by chemical pesticides has resulted to several problems such as development of resistance in pests and raising environmental and health concerns. Indeed, greenhouse crops are harvested frequently at short intervals, and thus intensive use of chemicals becomes questionable because of the possible contamination of products with chemical residues. Furthermore, most greenhouse vegetables are consumed fresh, which is another motivation for farmers to reduce intensive control measures and to meet the consumers' demands for offering products of high quality. The possibility to apply biological control programs against greenhouse pests is highly needed. It can overcome the abovementioned problems, and at the same time they can provide an adequate pest control. They will not completely eliminate pest problems but can reduce pest populations and damage to an acceptable level (under the economical threshold). Biological control generally requires more time than pesticides to bring a pest population under an acceptable control level (Kortam 2019).

The present study aimed to compare the feedback of implementing two pest control programs using biocontrol agents and chemical control of sweet pepper pests in greenhouses to outcome with an applicable safe and sanitation production program.

\section{Materials and methods}

The study was conducted in commercial greenhouse of $14,040 \mathrm{~m}^{2}(180 \mathrm{~mL} \times 78 \mathrm{~mW}$ and $4.5 \mathrm{~m}$ height $)$ located at Berkash district, Giza Governorate, Egypt, during the fall-winter pepper plantation season, 2016/17. The greenhouse was divided internally into 3 tunnels for BC, chemical control, and untreated tunnel (control). Three $\left[320 \mathrm{~m}^{2}\right.$ tunnels $\left.\left(40 \mathrm{~L} \times 8 \mathrm{~W} / \mathrm{m}^{2}\right)\right]$ were designed by installing plastic partitions, hermetically fixed to the greenhouse structure. This allowed the isolation of the tunnels from each other and avoided insects' transfer from one tunnel to another. Each tunnel included 4 rows of 90 sweet pepper plants (360 plants/tunnel) of Helenscy variety. Fifteen-centimeter-height sweet pepper plants were transplanted directly in soil during late summer (the 3rd week of August). The growing season extended from August 2016 to April 2017.

Population densities of the targeted pests, T. urticae, F. occidentalis, B. tabaci, and S.exigua, were estimated biweekly ( 15 days interval) throughout the plant growing season. Thirty randomized plants from each tunnel from the 3 levels of the plant (top, middle, and down) were directly inspected on the plant using a special magnifying hand lens $(\times 10)$.

Counts of moving stages were estimated for F. occidentalis and T. urticae. Adults, nymphs, and pupae of $B$. tabaci were recorded and the number of $S$. exigua larvae was also counted. Fourteen releases were carried out during the season starting from September 2016 to March 2017. The released bioagents in the biological control greenhouse (BCG) were the predators: O. albidipennis, at the rate of 4 nymphs $/ 4 \mathrm{~m}^{2}$ against $T$. urticae and $F$. occidentalis (releasing rate of $O$. albidipennis to control T. urticae and F. occidentalis was chosen according to El Arnaouty et al. 2018 and Elimem et al. 2018). For $M$. cali ginosus, it was at the rate of 2 nymphs $/ 2 \mathrm{~m}^{2}$ against B. tabaci (releasing rate of $M$. caliginosus was chosen according to Bonato et al. 2006), C. carnea at the rate of 4 larvae $/ 4 \mathrm{~m}^{2}$ (releasing rate of C. carnea was chosen according to El Arnaouty 1991), and the egg parasitoid T. euproctidis against S. exigua (for experimental release of $T$. euproctidis, a total of 2500 parasitoids were released biweekly in BCG). The bioagents were released before sampling on the same sampling day. All biological agents were obtained from the Laboratory of "Chrysopa mass production, Faculty of Agriculture, Cairo University, Giza, Egypt." In the chemical treated greenhouse (CCG), timing and rate of applications of different pesticides were determined by the grower, based on his assessment of pest populations (Table 1).

The produced yields of sweet pepper from each of the 3 greenhouses were estimated at the end of the season. As well, the cost-benefit estimations of the results of applying different pest control programs were carried out (Goda et al. 2015).

\section{Statistical analysis}

A randomized complete block design with 2 factors was used for analysis of all data with 30 replicates for each parameter. Significance between treatment means were compared by the least significant difference (L.S.D.) test as given by Snedecor and Cochran (1994), using Assistant program. 
Table 1 A list of pesticides applied to control sweet pepper pests in the greenhouse from September 8, 2016 to March 26, 2017

\begin{tabular}{|c|c|c|c|c|}
\hline Weeks of application & Trade name & Active ingredient & Target pest & Rates of application $\left(\mathrm{cm}^{3} / \mathrm{L}\right)$ \\
\hline 3 & Match 5\% EC & Lufenuron & S. exigua & $150 \mathrm{~cm}^{3} / 100 \mathrm{~L}$ \\
\hline 5 & Vertimec $1.8 \%$ EC & Abamectin & Mites & $200 \mathrm{~cm}^{3} / 200 \mathrm{~L}$ \\
\hline 6 & Radiant $12 \%$ SC & Spinetoram & S. exigua & $200 \mathrm{~cm}^{3} / 200 \mathrm{~L}$ \\
\hline 7 & Vertimec $1.8 \%$ EC & Abamectin & Mites & $200 \mathrm{~cm}^{3} / 200 \mathrm{~L}$ \\
\hline 9 & Alverde $24 \%$ SC & Metaflumizone & S. exigua & $150 \mathrm{~cm}^{3} / 100 \mathrm{~L}$ \\
\hline 9 & Calypso 48\% SC & Thiacloprid & sucking pests & $200 \mathrm{~cm}^{3} / 200 \mathrm{~L}$ \\
\hline 14 & Radiant $12 \%$ SC & Spinetoram & S. exigua & $200 \mathrm{~cm}^{3} / 200 \mathrm{~L}$ \\
\hline 16 & Kanemite 15\% SC & Abamectin & Mites & $200 \mathrm{~cm}^{3} / 200 \mathrm{~L}$ \\
\hline 17 & Alverde $24 \%$ SC & Metaflumizone & S. exigua & $150 \mathrm{~cm}^{3} / 100 \mathrm{~L}$ \\
\hline 20 & Oberon $24 \%$ SC & Spiromesifen & Mites & $200 \mathrm{~cm}^{3} / 200 \mathrm{~L}$ \\
\hline 21 & Kanemite 15\% SC & Acequinocyl & Mites & $175 \mathrm{~cm}^{3} / 200 \mathrm{~L}$ \\
\hline 23 & Kanemite 15\% SC & Acequinocyl & Mites & $175 \mathrm{~cm}^{3} / 200 \mathrm{~L}$ \\
\hline 24 & Vertimec $1.8 \%$ EC & Abamectin & Mites & $200 \mathrm{~cm}^{3} / 200 \mathrm{~L}$ \\
\hline 25 & Vertimec 1.8\% EC & Abamectin & Mites & $200 \mathrm{~cm}^{3} / 200 \mathrm{~L}$ \\
\hline 26 & Mospilan 20\% SP & Acetamiprid & sucking pests & $30 \mathrm{gm} / 100 \mathrm{~L}$ \\
\hline 27 & Calypso 48\% SC & Thiacloprid & sucking pests & $200 \mathrm{~cm}^{3} / 200 \mathrm{~L}$ \\
\hline 28 & Actra $25 \%$ WG & Thiamethoxam & sucking pests & $25 \mathrm{gm} / 100 \mathrm{~L}$ \\
\hline 29 & Calypso 48\% SC & Thiacloprid & sucking pests & $200 \mathrm{~cm}^{3} / 200 \mathrm{~L}$ \\
\hline
\end{tabular}

\section{Results and discussion}

In CCG, 3 pesticides (Match 5\% EC, Radiant 12\% SC, and Alverde 24\% SC) were applied against S. exigua started from the 3rd week after transplanted; 3 pesticides (Vertimec 1.8\% EC, Oberon 24\% SC, and Kanemite 15\% SC) were applied against $T$. urticae started from the 5 th week post cultivation. For the sap sucking pests including $B$. tabaci and F. occidentalis (Calypso 48\% SC, Mospilan 20\% SP, and Actra 25\% WG) were applied (Table 1). In the BCG, the bioagents were released on biweekly bases (at the same inspection day).

The mean numbers of thrips/flower are presented in Table 2. The mean numbers of thrips/flower in BCG and CCG were significantly lower than in the untreated

Table 2 Mean counts of thrips/flower in the sweet pepper greenhouse during the winter plantation of season of 2016-17

\begin{tabular}{|c|c|c|c|c|c|}
\hline \multirow{2}{*}{$\begin{array}{l}\text { Weeks of } \\
\text { inspection }\end{array}$} & \multicolumn{3}{|c|}{ Mean numbers of thrips/flower for different treatments } & \multirow[t]{2}{*}{$\mathrm{LSD}_{0.05}$} & \multirow{2}{*}{$\begin{array}{l}F \\
\text { value }\end{array}$} \\
\hline & Control & BCG & CCG & & \\
\hline 1 & $1.11 \pm 0.13^{\mathrm{a}}$ & $1.13 \pm 0.15^{\mathrm{a}}$ & $1.13 \pm 0.14^{\mathrm{a}}$ & 0.31 & 0.06 \\
\hline 3 & $1.63 \pm 0.21^{\mathrm{a}}$ & $1.43 \pm 0.22^{\mathrm{a}}$ & $1.57 \pm 0.25^{\mathrm{a}}$ & 0.51 & 0.12 \\
\hline 5 & $2.20 \pm 0.19^{\mathrm{a}}$ & $1.17 \pm 0.18^{b}$ & $1.67 \pm 0.2^{\mathrm{ab}}$ & 0.58 & 9.95 \\
\hline 7 & $4.40 \pm 0.53^{\mathrm{a}}$ & $1.83 \pm 0.52^{b}$ & $3.83 \pm 0.54^{\mathrm{a}}$ & 1.59 & 6.3 \\
\hline 9 & $5.27 \pm 0.77^{\mathrm{a}}$ & $1.88 \pm 0.95^{\mathrm{b}}$ & $3.00 \pm 0.8^{b}$ & 1.52 & 32.15 \\
\hline 11 & $7.41 \pm 0.14^{\mathrm{a}}$ & $1.80 \pm 0.56^{\mathrm{c}}$ & $3.36 \pm 0.45^{b}$ & 1.32 & 38.05 \\
\hline 13 & $7.59 \pm 0.45^{\mathrm{a}}$ & $1.64 \pm 0.64^{b}$ & $6.75 \pm 0.5^{a}$ & 2.14 & 10.12 \\
\hline 15 & $9.94 \pm 0.58^{a}$ & $2.17 \pm 0.71^{c}$ & $5.74 \pm 0.56^{b}$ & 1.69 & 3.12 \\
\hline 17 & $11.38 \pm 0.51^{\mathrm{a}}$ & $2.77 \pm 0.72^{b}$ & $4.37 \pm 0.57^{b}$ & 1.77 & 3.45 \\
\hline 19 & $16.82 \pm 0.84^{a}$ & $2.50 \pm 1.02^{c}$ & $6.60 \pm 0.81^{b}$ & 1.94 & 26.84 \\
\hline 21 & $19.82 \pm 0.94^{a}$ & $3.25 \pm 1.15^{c}$ & $7.59 \pm 0.91^{b}$ & 2.33 & 32.13 \\
\hline 23 & $22.50 \pm 0.83^{a}$ & $2.64 \pm 1.02^{c}$ & $8.18 \pm 0.86^{b}$ & 2.07 & 26.48 \\
\hline 25 & $23.11 \pm 1.07^{\mathrm{a}}$ & $2.90 \pm 1.31^{b}$ & $4.80 \pm 1.21^{b}$ & 2.71 & 47.6 \\
\hline 27 & $29.47 \pm 1.46^{\mathrm{a}}$ & $2.55 \pm 1.79^{b}$ & $7.14 \pm 1.66^{b}$ & 6.23 & 27.5 \\
\hline 29 & $30.40 \pm 1.27^{a}$ & $2.18 \pm 2.2^{c}$ & $12.40 \pm 1.8^{b}$ & 7.14 & 21.63 \\
\hline
\end{tabular}


greenhouse (control). Thrips infestation started on September 8, 2016, (1st week) when the mean numbers of thrips/ leaf were similar in the 3 experimental greenhouses. In the control, the population density of the thrips increased and continued until the end of the season to reach the highest number of thrips/leaf ( $30.40 \pm 1.27$ thrips/leaf) at week 29th.

$O$. albidipennis proved to be an efficient predator in maintaining the number of thrips under the economic threshold which is assumed to be 4.9 individuals/flower according to Ramchandra and Niann (2013). The lowest number of thrips/flower $(2.18 \pm 2.2$ thrips/leaf) was recorded in BCG. However, the mean number of thrips varied from $7.59 \pm 0.91$ thrips/leaf at week 21 st to $12.40 \pm 1.8$ thrips individuals/leaf at the week 29th in the CCG (Table 2).

In the BCG, the number of thrips/leaf $(2.18 \pm 2.2)$ was under the economic threshold by using 14 releases of $O$. albidipennis at the rate of 4 nymphs $/ 4 \mathrm{~m}^{2}$. Similar results were obtained by Kececi and Gurkan (2017), when they released O. laevigatus twice at the rate of 4 adults/ $\mathrm{m}^{2}$ to control $F$. occidentalis on sweet pepper in greenhouse. Elimem and Chermiti (2012) recorded that $F$. occidentalis population decreased to low average values of 0.42 and 0.06 thrips per flower, as a result of using the insect predator $O$. laevigatuson sweet pepper in a greenhouse in Tunisia. Additionally, Arno et al. (2008) reported that Orius species could serve as an important biological control agent for use in crops in which $B$. tabaci and F. occidentalis occur together.

The mean number of the whitefly/leaf in BCG and CCG was significantly lower than in the control. At the beginning of the experiment, the mean number of whitefly/leaf was similar in the 3 experimental greenhouses. In the control, the population density of the whitefly increased and continued up to the end of the season to reach the highest number (20.62 \pm 0.88 individuals/leaf) at the week 29th (Table 3).

Obtained results indicated that $M$. caliginosus proved to be efficient in maintaining the number of whitefly under the economic threshold as the lowest number of whitefly/leaf $(2.56 \pm 1.12)$ was recorded in the BCG. The economic threshold for B. tabaci was 4 adults/leaf (Shen et al. 2005). However, the mean number of whitefly ranged from $1.75 \pm 0.37$ whitefly/leaf at the week 21 st to $11.33 \pm 0.91$ at the week 29th at CCG (Table 3). The results agree with that of Rasdi et al. (2009) who reported that $M$. caliginosus is mainly used as a biological control auxiliary against the whitefly, Trialeurodes vaporariorum Westwood in the vegetable greenhouses (eggplant, tomato, and cucumber).

As shown in Table 4, in the control treatment, the number of the spider mite increased from the 3rd week and continued until the end of the season. According to Warabieda (2015), the economic threshold of the spider mite population density should not exceed 3 motile forms per leaf. The mean numbers of $T$. urticae/leaf are presented in Table 4. Analysis of data showed that there was a significant difference between each of the BCGs and CCG and the control. The mean numbers of T. urticae/leaf in the BCG and CCG were significantly lower than in the control. At the beginning of the experiment, the mean number of $T$. urticae/leaflet was similar in the 3 experimental greenhouses. In the control treatment, the population density of $T$. urticae increased gradually

Table 3 Mean counts of whitefly individuals/leaf on sweet pepper leaves in the greenhouse during the winter plantation of 2016/17

\begin{tabular}{|c|c|c|c|c|c|}
\hline \multirow{2}{*}{$\begin{array}{l}\text { Weeks of } \\
\text { inspection }\end{array}$} & \multicolumn{3}{|c|}{ Mean numbers of whitefly individuals/leaf for different treatments } & \multirow[t]{2}{*}{$\mathrm{LSD}_{0.05}$} & \multirow{2}{*}{$\begin{array}{l}\mathrm{F} \\
\text { value }\end{array}$} \\
\hline & Control & BCG & CCG & & \\
\hline 1 & $1.40 \pm 0.15^{\mathrm{a}}$ & $1.30 \pm 0.2^{a}$ & $1.17 \pm 0.17^{\mathrm{a}}$ & 0.78 & 0.71 \\
\hline 3 & $2.75 \pm 0.21^{\mathrm{a}}$ & $1.43 \pm 0.29^{b}$ & $1.71 \pm 0.22^{b}$ & 0.63 & 4.97 \\
\hline 5 & $4.80 \pm 0.24^{\mathrm{a}}$ & $1.90 \pm 0.30^{b}$ & $2.00 \pm 0.26^{\mathrm{b}}$ & 0.82 & 24.28 \\
\hline 7 & $9.62 \pm 0.35^{a}$ & $1.50 \pm 0.5^{\mathrm{b}}$ & $1.92 \pm 0.37^{b}$ & 1.25 & 50.54 \\
\hline 9 & $5.17 \pm 0.38^{\mathrm{a}}$ & $2.64 \pm 0.54^{b}$ & $4.17 \pm 0.4^{\mathrm{ab}}$ & 0.92 & 4.62 \\
\hline 11 & $5.47 \pm 0.40^{\mathrm{a}}$ & $2.87 \pm 0.42^{b}$ & $5.23 \pm 0.42^{a}$ & 1.41 & 11.33 \\
\hline 13 & $4.47 \pm 0.56^{\mathrm{a}}$ & $2.45 \pm 0.58^{b}$ & $4.50 \pm 0.58^{a}$ & 1.70 & 5.44 \\
\hline 15 & $3.94 \pm 0.42^{\mathrm{a}}$ & $2.12 \pm 0.43^{b}$ & $2.33 \pm 0.43^{b}$ & 1.12 & 6.17 \\
\hline 17 & $4.05 \pm 0.28^{\mathrm{a}}$ & $2.06 \pm 0.31^{b}$ & $2.30 \pm 0.39^{b}$ & 1.60 & 13.60 \\
\hline 19 & $3.17 \pm 0.41^{\mathrm{a}}$ & $1.93 \pm 0.36^{b}$ & $1.75 \pm 0.5^{b}$ & 1.14 & 3.73 \\
\hline 21 & $3.75 \pm 0.26^{\mathrm{a}}$ & $2.13 \pm 0.29^{b}$ & $1.75 \pm 0.37^{\mathrm{ab}}$ & 1.50 & 4.01 \\
\hline 23 & $7.19 \pm 0.35^{\mathrm{a}}$ & $2.89 \pm 0.45^{b}$ & $2.45 \pm 0.37^{b}$ & 2.15 & 45.34 \\
\hline 25 & $9.94 \pm 0.55^{a}$ & $3.09 \pm 0.69^{b}$ & $3.88 \pm 0.56^{b}$ & 3.27 & 37.48 \\
\hline 27 & $15.60 \pm 0.93^{a}$ & $2.88 \pm 1.18^{b}$ & $7.64 \pm 0.96^{b}$ & 3.54 & 34.32 \\
\hline 29 & $20.62 \pm 0.88^{a}$ & $2.56 \pm 1.12^{b}$ & $11.33 \pm 0.91^{b}$ & 4.12 & 70.76 \\
\hline
\end{tabular}

Means followed by the same letter at the same row are not significantly different $(p \leq 0.05)$ 
Table 4 Mean counts of T.urticae/leaf on the sweet pepper in the greenhouse during the winter plantation of 2016/17

\begin{tabular}{|c|c|c|c|c|}
\hline \multirow{2}{*}{$\begin{array}{l}\text { Weeks of } \\
\text { inspection }\end{array}$} & \multicolumn{3}{|c|}{ Mean numbers of T.urticae/leaf on different treatments } & \multirow[t]{2}{*}{$\mathrm{LSD}_{0.05}$} \\
\hline & Control & BCG & CCG & \\
\hline 1 & $1.56 \pm 0.5$ & $1.62 \pm 0.08$ & $1.50 \pm 0.4$ & 0.78 \\
\hline 3 & $4.11 \pm 0.2$ & $1.75 \pm 1.2$ & $1.70 \pm 0.6$ & 0.63 \\
\hline 5 & $6.32 \pm 2.2$ & $3.00 \pm 1.3$ & $4.00 \pm 1.2$ & 0.82 \\
\hline 7 & $6.57 \pm 1.5$ & $2.78 \pm 2.1$ & $6.83 \pm 1.9$ & 1.25 \\
\hline 9 & $7.21 \pm 2.3$ & $3.00 \pm 1.1$ & $4.57 \pm 1.2$ & 0.92 \\
\hline 11 & $10.57 \pm 2.3$ & $4.40 \pm 1.23$ & $6.73 \pm 1.3$ & 1.41 \\
\hline 13 & $10.43 \pm 3.1$ & $3.43 \pm 0.2$ & $7.07 \pm 1.3$ & 1.70 \\
\hline 15 & $10.57 \pm 2.2$ & $2.73 \pm 0.8$ & $10.17 \pm 2.5$ & 1.12 \\
\hline 17 & $9.97 \pm 3.4$ & $1.13 \pm 0.9$ & $7.37 \pm 2.1$ & 1.60 \\
\hline 19 & $15.12 \pm 3.5$ & $1.83 \pm 0.5$ & $8.37 \pm 2.4$ & 1.14 \\
\hline 21 & $12.03 \pm 2.9$ & $1.63 \pm 0.6$ & $11.13 \pm 3.1$ & 1.50 \\
\hline 23 & $19.11 \pm 2.4$ & $4.30 \pm 0.7$ & $12.48 \pm 4.2$ & 2.15 \\
\hline 25 & $28.24 \pm 5.6$ & $6.68 \pm 0.8$ & $21.44 \pm 5.3$ & 3.27 \\
\hline 27 & $36.33 \pm 5.3$ & $4.93 \pm 1.5$ & $17.25 \pm 4.5$ & 3.54 \\
\hline 29 & $42.70 \pm 7.4$ & $2.90 \pm 1.2$ & $20.13 \pm 3.9$ & 4.12 \\
\hline
\end{tabular}

and continued up to the end of the season to reach the highest number/leaf $(42.70 \pm 7.4$ mite individuals/leaf $)$ at the week 29th.

Although the 3pesticides (Vertimec 1.8\% EC, Oberon 24\% SC, and Kanemite 15\% SC) were applied 8 times against $T$. urticaein CCG, the mean number of $T$. urticae/leaf in the CCG continued to increase to reach 20.13 $\pm 3.9 \mathrm{mites} / \mathrm{leaflet}$. The pesticide application started from the 5th week post cultivation in the CCG.

The economic threshold of $S$. exigua was 2.3 larvae per plant (Capinera 2014). T. euproctidis releases were efficient in controlling $S$. exigua since the lowest number of $S$. exigua larvae $(1.6 \pm 2.06$ larvae/plant $)$ was recorded in the BCG. However, in the CCG, the mean number of
S. exigua larvae varied from $4.7 \pm 0.79$ larvae/plant on the 3rd week to $8.8 \pm 1.32$ larvae/plant on the 21 st week. Fourteen releases of $T$. euproctidis resulted in reducing the mean number of $S$. exigua larvae $(1.6 \pm 2.06$ larvae/ plant; Table 5). These results confirmed those obtained by Mahmoud et al. (2011) who reported that releasing of T. evanescens West. reduced the numbers of $S$. exigua larvae than their numbers in control fields.

\section{Sweet pepper yield}

The highest yield production of sweet pepper $(913.76 \mathrm{~kg}$; $35.06 \%$ increase than control) was recorded in the BCG, followed by the CCG $(750.2 \mathrm{~kg} ; 17.88 \%$ less $)$ than in the BCG (Table 6). Obtained results confirmed those obtained

Table 5 Mean counts of S. exigua larvae/sweet pepper plant in greenhouse during the winter plantation 2016-2017

\begin{tabular}{|c|c|c|c|c|c|}
\hline \multirow{2}{*}{$\begin{array}{l}\text { Week of } \\
\text { inspection }\end{array}$} & \multicolumn{3}{|c|}{ Mean counts of S. exigua larvae/sweet pepper plant for different treatments } & \multirow[t]{2}{*}{$\mathrm{LSD}_{0.05}$} & \multirow{2}{*}{$\begin{array}{l}F \\
\text { value }\end{array}$} \\
\hline & Control & BCG & CCG & & \\
\hline 1 & $2.1 \pm 0.5^{b}$ & $2.9 \pm 0.05^{\mathrm{ab}}$ & $2.3 \pm 0.54^{\mathrm{a}}$ & 0.85 & 3.15 \\
\hline 3 & $2.3 \pm 0.52^{b}$ & $3.6 \pm 0.56^{\mathrm{ab}}$ & $4.7 \pm 0.79^{\mathrm{a}}$ & 1.59 & 4.5 \\
\hline 5 & $5.1 \pm 0.79^{a}$ & $2.6 \pm 1.12^{b}$ & $7.1 \pm 0.81^{a}$ & 2.25 & 8.4 \\
\hline 7 & $8.3 \pm 1.61^{\mathrm{a}}$ & $2.2 \pm 2.03^{b}$ & $10.2 \pm 1.61^{\mathrm{a}}$ & 1.45 & 5.85 \\
\hline 9 & $10.0 \pm 1.02^{\mathrm{a}}$ & $3.4 \pm 1.44^{b}$ & $7.4 \pm 1.02^{\mathrm{a}}$ & 2.89 & 10.49 \\
\hline 11 & $21.2 \pm 1.53^{\mathrm{a}}$ & $3.7 \pm 2.17^{c}$ & $8.4 \pm 1.51^{b}$ & 4.36 & 34.73 \\
\hline 13 & $18.1 \pm 1.68^{a}$ & $4.7 \pm 1.68^{c}$ & $12.5 \pm 1.85^{b}$ & 2.01 & 15.93 \\
\hline 15 & $19.1 \pm 2.42^{\mathrm{a}}$ & $4.1 \pm 3.09^{b}$ & $15.1 \pm 3.39^{b}$ & 7.42 & 9.28 \\
\hline 17 & $25.2 \pm 3.39^{a}$ & $3.2 \pm 3.42^{b}$ & $21.4 \pm 2.14^{\mathrm{a}}$ & 6.86 & 14.22 \\
\hline 19 & $27.4 \pm 2.82^{\mathrm{a}}$ & $2.1 \pm 3.99^{c}$ & $12.8 \pm 2.28^{\mathrm{b}}$ & 7.99 & 16.82 \\
\hline 21 & $29.2 \pm 1.45^{a}$ & $1.6 \pm 2.06^{c}$ & $8.8 \pm 1.32^{b}$ & 4.13 & 37.74 \\
\hline
\end{tabular}

Means followed by the same letter at the same row are not significantly different $(p \leq 0.05)$ 
Table 6 Total yield production, controlling costs, and cost benefits of sweet pepper after using biological and chemical control, and the untreated control in the experimental tunnels

\begin{tabular}{lllll}
\hline Treatments & Yield/treatment (kg) & Production price (L.E.) & Controlling costs (L.E.) & Cost benefits (L.E.) \\
\hline Control & 593.36 & 7417 & 0 & 7417 \\
BC & 913.76 & 11,422 & 577 & 10,845 \\
CC & 750.2 & 9377.5 & 801.22 & 8576.2 \\
\hline
\end{tabular}

by Adly (2015) who recorded (40\%) increase achieved in cucumber yield, when applied biological control program in a cucumber greenhouse.

\section{Cost benefits}

The cost of releasing biocontrol agents/treatment was 112 L.E. for O. albidipennis, 280 L.E for M. caliginosus, 80 L. E for Ch. carnea, and 105 L.E. for T. euproctidis (Table 5). Throughout the whole growing season, the 14 releases of bioagents' cost was 577 L.E. (about 35.4 US \$). However, the 18 applications of the pesticides cost was 801.22 L.E. (about 49.1 US \$). The cost benefits of the BC program were (31.61 and 26.45\%) higher than the control and the chemical control program, respectively.

\section{Conclusion}

Implementing a biological control program, by releasing different predators and parasitoids, achieved an applicable safe and sanitation production program of sweet pepper greenhouse production, compared with the recommended chemical control program under the same circumstances. For the yield, the biological control program resulted about 35.06 and $17.88 \%$ increase over the control and the chemical control program, respectively. Also, applying $\mathrm{BC}$ program resulted the highest cost benefits to sweet pepper production (31.61 and 26.45\% higher than the control and chemical control program).

\section{Acknowledgements}

The writers express their deep thanks to STDF project number 30009 for funding this study, also to Techno green farming company, especially to Eng. Mohamed Kamal who offered the opportunity to carry out the present assay in the farm greenhouses. Special thanks for the Chrysopa Mass Production laboratory at Faculty of Agriculture, Cairo University.

\section{Authors' contributions}

Field Application was carried out by MNK. SAEA performed the design of the study. SAEA, A HE, AIA, and $I H H$ revised the manuscript. SAEA and A HE were major contributors in revising the manuscript. All authors read and approved the final manuscript.

\section{Availability of data and materials}

All data generated or analyzed during this study are included in this published article.

\section{Ethics approval and consent to participate}

Not applicable

\section{Consent for publication}

Not applicable
Competing interests

The authors declare that they have no competing interests

\section{Author details}

${ }^{1}$ Department of Economic Entomology and Pesticides, Chrysopa Mass Production Laboratory, Faculty of Agriculture, Cairo University, Giza, Egypt. ${ }^{2}$ Plant Protection Research Institute, Agricultural Research Center, Giza, Egypt. ${ }^{3}$ Central Laboratory of Organic Agriculture, Agricultural Research Center, Giza, Egypt.

Received: 10 October 2019 Accepted: 26 February 2020

Published online: 18 March 2020

\section{References}

Adly D (2015) Comparative study of biological and chemical control programs of certain cucumber pests in greenhouses. Proceeding of $4^{\text {th }}$ International Conference, ESPCP2015, Cairo, Egypt, 19-22 October Egypt. Egypt J Biol Pest Control 25(3):691-696

Adly D (2016) Use of predators for controlling the whitefly, Bemisia tabaci Genn. and the two spotted spider mite, Tetranychus urticae Koch. in cucumber greenhouses in Egypt. Egypt J Biol Pest Control 26(4):701-706

Arno J, Roig J, Riudavets J (2008) Evaluation of Orius majusculus and O. laevigatus as predators of Bemisia tabaci and estimation of their prey preference. Biological Control 44(1):1-6

Bonato O, Couton L, Fargues J (2006) Feeding preference of Macrolophus caliginosus (Heteroptera: Miridae) on Bemisia tabaci and Trialeurodes vaporariorum (Homoptera: Aleyrodidae). J Econ Entomol 99(4):1143-1151

Capinera, J.L. 2014. Beet armyworm, Spodoptera exigua (Hübner) (Insecta: Lepidoptera: Noctuidae). University of Florida/IFAS Extension. Publication EENY-105. Available at: http://entnemdept.ufl.edu/creatures/veg/leaf/beet_ armyworm.htm

Driesche RG, Lyon S, Stanek SE, Nunn C (2006) Evaluation of efficacy of Neoseilus cucumeris for control of western flower thrips in spring bedding crops. Biological control 36:203-215

El Arnaouty SA (1991) Studies on the biology and manipulation of Chrysoprela carnea (Stephens) and Chrysoperla sinica (Tjeder) (Neuroptera: Chrysopidae) for controlling the green peach aphid Myzus persicae (Sulzer)(Homoptera: Aphididae) in green-houses. Ph.D. thesis. Faculty of Agriculture, Cairo University, p 247

El Arnaouty SA, Kortam MN, Afifi Al, Heikal IH (2018) Orius albidipennis (Rueter) as an effective biocontrol agent against Tetranychus urticae Koch on pepper crops in greenhouse in Egypt. Egypt J Biol Pest Control, https://doi.org/10. 1186/s41938-018-0045-0(2018):28-42

Elimem M, Chermiti B (2012) Use of the predators Orius laevigatus and Aeolothrips spp. to control Frankliniella occidentalis populations in greenhouse peppers in the region of Monastir, Tunisia. IOBC/WPRS Bull 80:141-146

Elimem M, Harbi A, Sellemi E, Othmen S, Chermiti B (2018) Orius laevigatus (Insecta; Heteroptera) local strain, a promising agent in biological control of Frankliniella occidentalis (Insecta; Thysanoptra) in protected pepper crops in Tunisia. Euro Mediterr J Environ Integr. 3:5. https://doi.org/10.1007/s41207017-0040-y

El-Laithy AYM, Elseedy EMA, El-Kholi MY, Abou-Ellela MM, Svobodova Z (2013) Population dynamics of major insect and mite pests and control on sweet pepper grown in net house in Egypt. Integrated Control of Plant Mites. IOBC/WPRS Bull 93:31-38

Ginette YA, Simon F, Serge K, Komi KM, Fiaboe S, Subramanian M, Thibaud M (2014) Dispersal behavior of Tetranychusevansi and T. urticae on tomato at several spatial scales and densities: implications for integrated pest management. Plos One 9(4):e950

Goda NF, El-Heneidy AH, Djelouah K, Hassan N (2015) Integrated pest management of the tomato leaf miner, Tutaabsoluta (Meyrick) (Lepidoptera: 
Gelechiidae) in tomato fields in Egypt. Proceeding of $4^{\text {th }}$ International Conference, ESPCP2015, Cairo, Egypt, 19-22 October Egypt. Egypt J Biol Pest Control 25(3):655-661

Heikal IH, Ebrahim AA (2013) Biological control of Tetranychus urticae Koch on sweet pepper plantation in a commercial farm by the predatory mite Phytoseiulus macropilis (Banks). Egypt J Agric Res 91(3):1161-1171

Kececi M, Gurkan MO (2017) Comparison of Orius niger with Orius laevigatus biological control efficiency to western flower thrips (Frankliniella occidentalis Pergande) on sweet pepper in greenhouses. Acta Horticulturae 1164:399406

Kortam MN (2019) Biological control of certain greenhouse pests. Ph.D. thesis. Faculty of Agriculture, Cairo University, p 248

Lasa R, Pagola I, Ibanez I, Belda J, Williams T, Caballero P (2007) Efficacy of Spodoptera exigua multiple nucleopolyhedro virus as a biological insecticide for beet armyworm control in greenhouses of southern Spain. Biocontrol Sci Technol 17:221-232

Mahmoud MA, Ibrahim IL, El-Shorbagy MSM, Mohisen MAA (2011) Evaluate the applied of the egg parasitoid Trichogramma evanesces WEST. to reduce the infestation of the lesser worm Spodoptera exigua HB. in sugar beet fields at El Aiat region, Giza governorate. J Plant Prot Path Mansoura Univ 2(8):741-747

Ramchandra Y, Niann T (2013) Economic thresholds of Thrips palmi

(Thysanoptera: Thripidae) for eggplants in a greenhouse. Appl Entomol Zool 48(2): 195-204

Rasdi Z, Fauziah I, Wan Mohamad WAK (2009) Biology of Macrolophus caliginosus (Heteroptera: Miridae) predator of Trialeurodes vaporariorum (Homoptera: Aleyrodidae). Int J Biol 1(2):63-70

Shen BB, Ren SX, Musa PH, Chen C (2005) A study on economic threshold of Bemisia tabaci. Acta Agric Universitatis Jiangxiensis 27(2):234-237

Snedecor GA, Cochran WG (1994) Statistical Method. Iowa State Univ. Press, Ames

Wakamura S (1990) Reproduction of the beet armyworm, Spodoptera exigua (Hübner) (Lepidoptera: Noctuidae), and influence of delayed mating. Jap J Appl Entomol Zool 34:43-48

Warabieda W (2015) Effect of two-spotted spider mite population (Tetranychus urticae Koch) on growth parameters and yield of the summer apple cv. Katja. Hort Sci (Prague) 42(4):167-175

\section{Publisher's Note}

Springer Nature remains neutral with regard to jurisdictional claims in published maps and institutional affiliations.

\section{Submit your manuscript to a SpringerOpen ${ }^{\circ}$ journal and benefit from:}

- Convenient online submission

- Rigorous peer review

- Open access: articles freely available online

- High visibility within the field

- Retaining the copyright to your article

Submit your next manuscript at $\boldsymbol{\nabla}$ springeropen.com 